\title{
THE JUDICIAL INTERPRETATION OF PUBLIC UTILITY FRANCHISES
}

\author{
RICHARD J. SMITH
}

The United States Supreme Court has recently added one more decision to the long list of cases on the contractual aspects of public utility franchises. 1 The specific question before the court was the review of a permanent injunction granted by a federal district court of three judges to restrain the railroad commission of California from enforcing against the Los Angeles Railway Corporation the provisions for rates of fare embodied in a series of franchises under which the company operated. The franchises had been granted successively from 1886 to 1928 and had provided generally that the rate of fare should not exceed five cents, although in some of the later ordinances it was also stated that an increase might be permitted by proper showing before "a competent authority having jurisdiction over rates of fare. .."

The company had applied to the railroad commission for a higher rate in 1918, but being dissatisfied with the small increase the commission was willing at that time to approve, subsequently withdrew its application. In 1926 the company again appealed to the commission for an increase. The appeal was denied. Suit was brought in the federal courts on the issue of confiscation and the city intervened as party defendant, alleging the inviolability of the existing franchise provisions.

Mr. Justice Butler, writing the majority opinion for the Supreme Court, concluded:

(1) The city had never been empowered by the state to make contracts for a limitation of the rate of fare.

(2) Granting the existence of a contract, the assumption of jurisdiction by the commission in 1918 and 1926 amounted to an abrogation of the contract.

The decree of the lower court was therefore affirmed. Mr. Justice McReynolds suggested in a cryptic concurrence that a finding that the city had no power to make a contract was sufficient to dispose of the case. A dissenting opinion read by Mr. Justice Brandeis maintained the following propositions:

(1) The mere statutory creation of the railroad commission could not effect an abrogation of existing contracts between the city and the company.

\footnotetext{
1 Railroad Commission v. Los Angeles Ry., 50 Sup. Ct. 71 (U. S. 1929).
} 
(2) The inconclusive proceedings before the commission in 1918 were equally ineffective.

(3) The actual holding of the commission in 1926 against an increase could not have the anomolous effect of abrogating a contract to maintain rates found to be reasonable.

(4) "Lack of power in the municipality to bind itself is a factor to be considered in determining whether the parties intended to enter into a contract. But, if they did, the railway's promise need not fail for lack of mutuality. The law does not require that a particular contractual obligation must be supported by a counter obligation."

(5) In any case, the question of the power of the city is one of state law, and questions of statutory construction and other matters of detail ought to have been decided first by the trial court.

Mr. Justice Brandeis, therefore, recommended that the judgment of the district court be vacated and the case remanded for further proceedings, with an interlocutory injunction to prevail pending the trial court's new decision. Mr. Justice Holmes concurred in this dissent. Mr. Justice Stone read a separate dissent, agreeing substantially with Mr. Justice Brandeis, but urging further that the company had at least contracted away protection under the due process clause of the fourteenth amendment.

Thus is recorded the latest pronouncement upon a question which has been before the courts since the days when the necessity for curbing profits claimed by utility companies under the terms of state charters first led the judges to circumvent the decision in the Dartmouth College case. ${ }^{2}$ But this latest decision seems to reflect neither an end of the litigation nor an immediate solution of the problem. Rather, it is but another example of the extent to which a matter of public policy has become shrouded with the technicalities of the judicial process.

To one uninitiated in the secrets of the judicial process the question would seem to be merely one of ascertaining the extent to which a previously existing agreement between the company and the community should affect the determination of a reasonable rate, assuming that reasonableness is a variable which depends upon the circumstances of individual cases, rather than upon rigid formulae. Yet the Supreme Court finds it necessary (a) to ascertain the powers of an artificial municipality as derived from an equally artificial body called the state; (b) to range those powers in opposition to the organism of another entity designated the state commission; (c) to introduce the technical rules of private contracts; (d) having thus rationalized

2 Trustees of Dartmouth College v. Woodward, 4 Wheat. 518 (U. S. 1819). 
the agreement between the members of the community and the company out of existence, to proceed to determine the reasonable rate as if the factual agreement had never at any time been in the case.

The extent to which the judicial process has become petrified by this technique is strikingly exhibited even in the dissents. Neither Mr. Justice Brandeis nor Mr. Justice Stone is prepared to discard the doctrines of the majority as the mere outgrowth of a haphazard evolution and, therefore, analytically irrelevant. Both accept the functioning of artificial political units without determining the extent to which those functions, and particularly the juxtaposition of functions, may be the results of the procreative activities of the courts themselves. Both transpose from the realm of private commercial transactions the common law rules of contracts upon which to predicate the issue of public policy. It is true that the dissents do imply a difference of opinion as to the result. But the disagreement is over the application of the formula rather than over the formula itself, so that, even were the dissenting opinions eventually to win the approval of a majority, the problem would be no nearer solution. Mr. Justice Brandeis, however, does give voice to a wholesome ennui.

But before the grounds of a real dissent can be stated it is, unfortunately, necessary to trace the evolution of the decisions which have produced the Los Angeles case. The problem was introduced into litigation at a time when courts and legislatures were bending their efforts to nullify the effect of the Dartmouth College case, which had declared that the charter of a college in New Hampshire was a contract protected by the federal constitution from change or alteration by the acts of subsequent legislatures. It should be unnecessary to suggest that this policy of nullification was being stoutly resisted by affected interests whose move in the wake of the Dartmouth College case was to consolidate the gains as quickly as possible. The issue was most sharply drawn in the case of charters which had been granted to public utility companies. As was to be expected, the private entrepreneurs had generally outwitted the representatives of the nublic in the negotiations for the charters. Wide powers had been surrendered in return for conditions that permitted exorbitant profits. It was natural that a disillusioned public would eventually seek to rectify the original grant.

Thus, in 1831, the Supreme Court of Maine was confronted with the issue in a case involving the franchise to operate a logboom. ${ }^{3}$ The action was in assumpsit by the proprietors of the loom, who sought to charge the defendant a fee which he claimed was prohibited by' an act of the legislature. The company had

3 Proprictors of Side Booms v. Haskell, 7 Mfe. 474 (1831). 
been incorporated in 1805 . The legislators, with a foresight which at that early date was little short of clairvoyance, inserted in the charter the provision "that the fees aforesaid shall at all times be subject to revision and alteration of the legislature." In 1812, the legislature reduced the charges, reiterating the original provision respecting future alteration. In 1820, an act was passed raising the permissible charges to the original level, but without reciting the provision for future alteration. Subsequently the charges were again reduced by the legislature. The plaintiff, enlightened by the decision in the Dartmouth College case, urged that the categorical act of 1820 had exhausted the legislature's power to alter and had given rise to an unimpairable contract. The court, however, refused to be coaxed into such refinements of legislative intent, and, in holding for the defendant, declared:

"In aid of our construction we may well suppose that the right of revision and alteration was reserved to the legislature, because the experiment, being a new one, and the anticipated profits uncertain, such a power might be highly useful, if not necessary, to prevent an undue and unreasonable income to the corporation ..." "4

But the extent to which this realistic attitude was either forgotten or ignored in the cases that followed affords a striking example of judicial inefficiency.5 Indeed, in several of the cases the courts seemed totally unaware of the importance of considering the nature of the public utility transaction, but, upon the bare finding that no right to repeal or alter had been reserved by the legislature, held that statutes attempting to reduce the maximum charge stipulated in the original acts were unconstitutional impairments. ${ }^{6}$ Hamilton $v$. Keith ${ }^{2}$ declared that a charter of 1854 was unaffected by a statute of 1856 which, in keeping with the movement to nullify the Dartmouth College decision, had provided for the alteration and amendment of all charters. The court was also moved by the fact that the company had borrowed money and mortgaged its property on the basis of the original rate. And thus were sown the seed for regarding the transaction between the state and the company as a purely private business matter. In this connection Philadelphia, $W . \& B$. $R y . v$ Bowers $^{8}$ is significant. The railroad had been granted a charter in 1836, under which the directors were given uncondi-

\footnotetext{
Ibid. 478.

5 But cf. Proprietors of Machias Boom v. Sullivan, 85 Me. 343, 27 Atl. 189 (1893), in which the court follows its earlier decision.

6 Middlesex Turnpike Company v. Freeman, 14 Conn. 84 (1840); Hamilton v. Keith, $68 \mathrm{Ky} .458$ (1869).

${ }^{7}$ Supra note 6.

84 Houst. 506 (Del. 1873).
} 
tional supervision over rates. The court held that a statute passed in 1873 to prevent certain discriminations in passenger rates was an unconstitutional impairment, declaring that a charter is a contract and "is none the less protected against legislative interference, although the franchise granted be one in the exercise of which the public are interested, if, nevertheless the corporation itself be a private one." " The court went on to say:

“.... the legislature may at all times regulate the exercise of the corporate franchise by general laws passed in good faith for the legitimate ends contemplated by the State police powerthat is, for the peace, good order, health, comfort and welfare of society-but it cannot, under color of such laws destroy or impair the franchise itself, nor any of those rights and powers which are essential to its beneficial exercise." 10

Other cases adopted an attitude similar to that expressed by the Delaware court in the Bowers case." A charter was a contract and "the right to take tolls, fares or charges for freight is of the essence of such charter." 12 This was particularly true where the constitutional provision for the alteration of charters said that the power should not be exercised "to impair or destroy any vested corporate right." 13

But meanwhile two important changes occurred to influence the trend of decisions. As a result of the campaign to nullify the effect of the Dartmouth College case, state constitutions had been amended to reserve to the legislature the power to alter or amend charters granted to private entrepreneurs, and, in addition, legislatures generally refused to grant a charter without expressly reserving those powers. Furthermore, popular resentment at the inequitable results of transactions between railroad companies and representatives of the public, and at the gross abuses of public powers entrusted to the entrepreneurs, had crystallized into the great Granger movement which not even the courts could ignore. The result was that decisions became a series of rationalizations which, to be sure, accomplished the end of reducing railway tariffs, but which at the same time erected a citadel of legal dicta that has remained until the present day to obscure

9 1bid. 529.

30 Ibid. 537.

11 But it is interesting to compare Robertson v. Wilmington Traction Co., 7 Boyce 155, 104 Atl. 839 (Del. 1918), where the Delaware court, profiting by the evolutions of forty-five years, was able to sustain the company's arguments against the existence of a contract albeit the old Bowers case was resurrected to goad the court with the charge of inconsistency.

12 Iron Ry. v. Lawrence Furnace Co., 29 Ohio St. 208 (1876); cf. Pingree v. Michigan Central Ry., 118 Mich. 314, 76 N. W. 635 (1898); Canæda Southern Ry. v. International Bridge Co., 8 Fed. 190 (N. D. N. Y. 1881).

${ }^{13}$ Ex parte Koehler, 23 Fed. 529 (C. C. D. Ore. 1885). 
the fundamental question in the interpretation of a public utility franchise.

The technical problem became one of construing the charter of the company either in relation to general statutes retaining the power of alteration in the legislature or in relation to constitutional amendments conferring such power upon subsequent legislatures. ${ }^{14}$ The Minnesota Supreme Court in Blake v. Winona $\&$ St. Peter $R y .{ }^{15}$ adopted a ratio decidendi reminiscent of the early Maine case, ${ }^{16}$ the implications of which might well have been followed in later decisions. For, while the court discussed "contract," it also argued that the only contract between the state and the railroad was that the latter should have the right to make some charge, a contract with which a legislative act fixing a maximum charge was not inconsistent. Moreover, the right to charge for public services, it was pointed out, might not be considered a true contract at all, but rather as arising out of a grant from the state. Other state courts, however, took the Dartmouth College case more seriously. ${ }^{27}$

But it was the United States Supreme Court which managed to clothe the issue completely with technicalities when the question came before that court in the Granger cases of 1876. In Chicago, B. \& Q. Ry. v. Iowa, ${ }^{18}$ Chief Justice Waite solemnly declared that a charter was a contract "subject only to the limitations and reservations in the charter or in the laws or constitutions which govern it." And, since such reservations obviously had been made, the company could not object to a subsequent state statute setting a lower maximum of charge. He pointed out:

"It was within the power of the company to call upon the legislature to fix permanently this limit, and make it a part of the charter; and, if it was refused, to abstain from building the road and establishing the contemplated business. If that had been done, the charter might have presented a contract against future legislative interference." 10

The court was further of the opinion that, since the company could not grant or pletge more than it had to give, it was immaterial that it had pledged its income as security for the payment of debts and had leased its road to a tenant who relied upon earnings for the means of payment. Thus, the method of deciding the case was first to admit the possibility of a contract,

14 Parker v. Metropolitan Ry., 109 Mass. 506 (1872).

1519 Minn. 418 (1872).

${ }^{26}$ Supra note 3.

${ }^{17}$ Attorney General v. Chicago \& Northwestern Ry., 35 Wis. 425 (1874); American Coal Co. v. Consolidated Coal Co., 46 Md. 15 (1876); Illinois Central Ry. v. People, 95 Ill. 313 (1880); Winchester Turnpike Road Co. v. Croxton, 98 Ky. 739, 34 S. W. 518 (1896).

1894 U. S. 155 (1876).

10 Ibid. 162. 
lest the memory of the Dartmouth College case be desecrated, then so to limit the scope of the contract as to preserve the constitutionality of the statute assailed.

This method gave rise to the rule that grants of immunity from legislative control were not to be presumed.:0 Thus, in 1885 Chief Justice Waite announced:

"This power of regulation is a power of government, continuing in its nature, and if it can be bargained away at all it can only be by words of positive grant, or something which is in law equivalent." 21

And Mr. Justice Field in 1888 reiterated:

“. ... the exemption must appear by such clear and unmistalable language that it cannot be reasonably construed consistently with the reservation of the power by the state. There is no such language in the present case."

The mischief of statements of this kind in opinions of the United States Supreme Court should be clear. Another veil is drawn across the main issue of the case. It is made to seem that the problem is one of defining words and, as a result, additional obscurities are manufactured in the struggle against the relativity of meanings. Then, too, constant reiteration of the "clear and unmistakable" jingle has concentrated attention upon the search for some technical latent contract which the court feels bound to negative. Finally, application of the general dictum in successive cases necessarily creates new variations which were not in the beginning implied.

The effect of this may be seen in the decision of Covington \& Lexington Turnpike Co.v. Sandford. ${ }^{23}$ The issue was whether the state of Kentucky might by injunctive proceedings require the company to observe an act of the legislature passed in 1890 establishing a lower scale of toll rates. The opinion of the United States Supreme Court proceeded from the general proposition that an intention to grant inalterable powers in a charter should not be imputed to the legislature "if it is possible to avoid doing so by any reasonable interpretation of its statutes." The "reasonable interpretation" was as follows:

(a) The turnpike company was incorporated under a charter

${ }^{20}$ Ruggles v. Illinois, 108 U. S. 526, 2 Sup. Ct. 832 (1882); of. Statc v. Columbus Gaslight \& Coke Co., 34 Ohio St. 572 (1878).

${ }^{21}$ Stone v. Farmers' Loan \& Trust Co., 116 U. S. 307, 325, 6 Sup. Ct. 334,342 (1886).

22 Georgia Railroad \& Banking Co. v. Smith, 128 U. S. 174, 182, 9 Sup. St. 47,50 (1888).

${ }^{23} 164$ U. S. 578, 17 Sup. Ct. 198 (1896). 
in 1834 which gave the directors authority to set rates to produce a yearly income of fourteen per centum on the investment.

(b) By an act of 1851, the original company was divided into two companies but the act stipulated that each company was to possess and retain all the powers, rights and capacities in severalty granted by the act of incorporation and amendments thereto to the original company.

(c) By this act of 1851 , the original company was absolutely dissolved and two new corporations formed, and, since the fourteen per centum clause had not been expressly set out in the act of 1851 , the surrender of legislative authority was not to be implied.

It should be noted, however, that the Turnpike Company case was not the first to take advantage of any potential effect of reorganization or consolidation upon the continued existence of the contract.24 The dissolution of a possible contract by this means was effected particularly where a general incorporation act or constitutional amendment reserving the power to alter intervened between the date of the original charter and that of the reorganization. ${ }^{25}$ There is, perhaps, no more striking example of the complexities of the problem thus created than People's Gas Light \& Coke Co. v. Chicago, ${ }^{26}$ where the court wanders through a maze of state acts and city ordinances reflecting the evolution of the corporate structure of the company, finally to arrive at the conclusion that any alleged contract rights contained in the original charter were lost because the constitution of 1870 came before the acts of ultimate consolidation.

As has been pointed out, in these cases dealing with the attempts of the state legislature directly to curb the exorbitant advantages accruing to private operators of public utilities in charters secured by devious methods, the problem was to avoid the Dartmouth College decision. This was thought to require judicial refinements upon the nature of a contract and the dignity

${ }^{24}$ Cf. Shields v. State, 26 Ohio St. 86 (1875) ; Peik v. Chicago \& Northwestern Ry., 94 U. S. 164 (1876) ; Owen v. St. Louis \& San Francisco Ry., 83 Mo. 454 (1884).

25 Dow v. Beidleman, 49 Ark. 325, 5 S. W. 297 (1887); Northern Central Ry. v. Maryland, 187 U. S. 258,23 Sup. Ct. 62 (1902). But of. Ball v. Rutland Ry., 93 Fed. 513 (C. C. D. Vt. 1899).

${ }_{26} 194$ U. S. 1, 24 Sup. Ct. 520 (1904). A variation of these cases is to be found in Cleveland v. Cleveland City Ry., 194 U. S. 517, 24 Sup. Ct. 756 (1904), which, however, deals chiefly with city ordinances; of. Board of Trustees v. City of Henderson, 196 N. C. 687,146 S. E. 808 (1929), whore for the purpose of relieving the city of duties to furnish water to a school the court held that the surrender of a franchise back to the city togethor with the purchase of the physical plant by the city did not amount to an assignment of a contract embodied in the franchise as it had first been granted to the water company. 
of legislative bodies. If the only situation had been the conflict between direct legislative action and charter privileges, it is probable that these judicial refinements might ultimately have been relegated to the oblivion of all other types of ad hoc dicta, and the rule that the legislature may alway's vary charter privileges might finally have been accepted without further, or at least, without persistent litigation in the future. But, in the meantime, a new situation had arisen. The city had become an important unit of population. The legislature had learned the value of delegating to a local council the power to legislate on local affairs. Questions arising over the obligations of a public service company therefore came to involve not merely the relation of charter privileges to direct action by the state legislature, but also the relation of such privileges to regulatory action by the local government.

This turn in the problem was foreshadowed in the United States Supreme Court as early as 1884 in Spring Valley Water Works $v$. Schottler.27 The constitution of California in 1849 declared that all general and special incorporation acts might be altered and repealed. In 1858 the Spring Valley Water Company was organized under an act providing generally for the incorporation of water companies but stipulating that rates to be charged should be determined by a board of commissioners, two to be appointed by the company and two by the supervisors of the municipality to be served. A new state constitution was adopted in 1879 which declared that rates of water companies should be fixed by ordinance of the municipality to be served. The Spring Valley company, having built up a private system to supply the city of San Francisco, objected that this new constitutional provision impaired the rate fixing obligation of the act of 1858. A majority of the court, in affirming the state court decision, held, on the basis of the reservation in the constitution of 1849, that the new provision was valid. Mr. Justice Field, however, in a long dissent suggested that the reservation of power to alter referred only to the privileges of incorporation and not to "contracts" entered into by a corporation already created.

Aside from the fact that the alleged impairment in this case was a constitutional provision delegating regulatory power to the local government, it would seem that the decision does nothing more than follow the Granger cases. But the dissent of Mr. Justice Field raised the point which was shortly to loom as the troublesome question of most future cases, namely, conceding the power of the state to alter charter provisions, to what extent could that power be utilized to alter an agreement between the company and the local body.

${ }_{27} 110$ U. S. 347,4 Sup. Ct. 48 (1884). 
Indeed, it was not long before Mr. Justice Field's dissent pro$\checkmark:$ ded lower courts with an opening for avoiding the majority decision in the Spring Valley case. In 1893, the federal circuit court in California had an issue before it similar to that in the Spring Valley case. ${ }^{28}$ The town of San Buenventura had been incorporated in 1866 with the power vested in the board of trustees to supply the town with fresh water. Three men agreed to furnish the water and construct the necessary plant if given the exclusive privilege for fifty years. The agreement was ratified by the board of trustees with the following provision: "The parties of the first part shall have the unrestrained right to establish such rates for the supply of water to private persons as they may deem expedient, provided such rates shall be general." In 1870 the Santa Ana Company was incorporated under the 1858 act mentioned above and, with the approval of the town, the original operators sold their system and all the rights thereof to the new company. Then came the constitution of 1879 giving the town trustees alone the right to fix the water rates. The court agreed with the Spring Valley case that the constitution of 1849 had made all charters alterable but, following $\mathrm{Mr}$. Justice Field, it held that here the contract in question had been made before any incorporation at all, and, being merely an agreement between three persons and the town, was subject to none of the constitutional provisions or acts of the legislature concerning corporations. New Orleams Gas Co. v. Louisiana Light Co. ${ }^{20}$ and Waterworks Co. v. Rivers ${ }^{30}$ were relied on to show that contracts with municipalities could not be impaired by subsequent acts of the legislature. The court, however, pointed out that the agreement was subject to the common law reservation that all charges by public utilities must be reasonable.

This deviation from the Spring Valley case soon found expression in a majority opinion of the United States Supreme Court.s2 The question was whether a provision in the franchise agreement between the company and the city reserving to the city the right to regulate the rates, on the condition that "they should not be reduced to less than those charged by the company at the time the agreement was made," disabled the city from reducing the rates below the initial level by an ordinance passed thirty years later. Mr. Justice McKenna, giving the opinion of the Court, held that the subsequent ordinance was an unconstitutional impairment. He sustained the original agreement as a contract on

${ }^{28}$ Santa Ana Water Co. v. Town of San Buenaventura, 56 Fed. 339 (C. C. S. D. Cal. 1893).

${ }^{29} 115$ U. S. 650,6 Sup. Ct. 252 (1885).

so 115 U. S. 674, 6 Sup. Ct. 273 (1885).

${ }^{31}$ Los Angeles v. Los Angeles City. Water Co., 177 U. S. 568, 20 Sup. Ct. 736 (1900). 
the ground that it did not grant away the power to regulate, but reserved the power and contracted for a limitation of that power. This opinion is an egregious example of the metaphysical morass into which the courts had wandered.

As the problem of these cases was the interpretation of language and the definition of words contained in constitutional provisions, state statutes and municipal ordinances it was impossible that one case could become satisfactory precedent for another. And when a case finally reached the United States Supreme Court the outcome was still more uncertain because of the varying weight that might be given the prior decisions of the state court, as against the rule that on the question of the existence of the contract the Supreme Court would exercise independent judgment.

Hence it is not surprising that a few years later in Freeport Water Co. v. Freeport City ${ }^{32}$ the Court, again speaking through Mr. Justice McKenna, should have construed a variety of Ilinois statutes and ordinances to find no contract preventing a reduction in rates. The fact that Mr. Justice White wrote a dissenting opinion with the concurrence of three of his associates in which, with cogency equal to that of the majority, he found that the statutes did embody a contract, is indicative not only of the uncertainty that had arisen, but also of the duplicity of the technical method. Nor was the situation improved when, the next year, a majority of the Court decided in Detroit v. Detroit Citizens Street $R y .^{33}$ that the company was protected by a contract. For, even though it be conceded that the disparity in the statutory expressions governing the two cases justified the difference in result, the fact remains that on the broad question of the interpretation of franchises the Court within a year had created two "leading cases," the reconciliation of which necessitated further resort to metaphysical technique. It would seem, however, that just as in the earlier Granger cases, the decisions following the $D e-$ troit case reflect a tendency to shape technical refinements to coincide with a policy of curbing corporate profits. ${ }^{36}$

32180 U. S. 587, 21 Sup. Ct. 493 (1901); cf. Rogers Park Water Co. v. Fergus, 180 U. S. 624, 21 Sup. Ct. 490 (1901).

${ }^{33} 184$ U. S. 368, 22 Sup. Ct. 410 (1902).

34 Successive Supreme Court decisions after the Detroit case are as follows: Knoxville Water Co. v. Knoxville, 189 U. S. 434, 23 Sup. Ct. 531 (1903) (reservations in general incorporation act held to prevent compang from asserting contract clause against reduction of rates); Ovrensboro $\nabla$. Owensboro Waterworks, 191 U. S. 667, 24 Sup. Ct. 853 (1903) (company's claim for contract denied because of absence of "clear and unmistakable intention") ; Stanislaus County v. San Joaquin Canal \& Irrigation Co., 192 U. S. 201, 24 Sup. Ct. 241 (1904) (rates could be reduced because constitutional provisions at the time of the company's incorporation stipulated that all general laws and special acts might be repealed); Tampa Water- 
Yet even with all these uncertainties in court decisions and discrepancies in statutory interpretations the basic issue could still be clearly discerned. Private operators sought to protect their profits by pressing the Dartmouth College case to its furthermost implication; the state, through the legislature and the court, was forced to resort to dialectic refinements to retain its control over agencies of public service. Every case might be reduced to this single contest. New factors, however, were soon to increase the perplexities. A change in economic conditions created demands for increased earnings in private investment. The operators found that the rate minimums in franchises against the reduction of which they had fought for many

works v. Tampa, 199 U. S. 241, 26 Sup. Ct. 23 (1905) (accord, Brown and Peckham, JJ., dissenting); San Antonio Traction Co. v. Altgelt, 200 U. S. 304, 26 Sup. Ct. 261 (1906). (accord); Home Telephone Co. v. Los Angeles, 211 U. S. 265, 29 Sup. Ct. 50 (1908) (no legislative authority permitting city to make alleged contract disabling it from subsequent action to reduce rates); Minneapolis v. Street Ry., 215 U. S. 417, 30 Sup. Ct. 118 (1910) (company protected where original franchise was ratified as contract by the state legislature); Cedar Rapids Gas Co. v. Cedar Rapids, 223 U. S. 655, 32 Sup. Ct. 389 (1912) (in accord with Tampa case, oupra.); Murray v. Pocatello, 226 U. S. 318, 33 Sup. Ct. 107 (1912) (same).

But the Detroit case itself has remained to inure to the benefit of public utility companies where the exigencies of corporation finance have demanded protection of the franchise. City of Rushville v. Rushville Natural Gas Co., 164 Ind. 162, 73 N. E. 87 (1904); Detroit United Ry. v. Michigan, 242 U. S. 238, 37 Sup. Ct. 87 (1916) ; Kings County Lighting Co. v. Cits of Now Yorls, 176 App. Div. 175, 162 N. Y. Supp. 581 (2d Dep't 1916), aff'd without opinion, 221 N. Y. 500, 116 N. E. 1055 (1917); Wichita Water Co. v. City of Wichita, 234 Fed. 415 (D. Kan. 1916); Iowa Railway \& Light Co. v. Jones Auto Co., 182 Iowa 982, 164 N. W. 780 (1917); Watertown v. Watertown Light \& Power Co., 42 S. D. 220, 173 N. W. 739 (1919); Detroit United Ry. v. Detroit, 248 U. S. 429, 39 Sup. Ct. 151 (1919); Villago of Wyoming v. Ohio Traction Co., 104 Ohio St. 325, 135 N. E. 675 (1922). But of. Lynchburg Traction \& Light Co. v. City of Lyncbburg, 16 F. (2d) 763 (C. C. A. 4th, 1927) where the company's allegation of impairmont was held unsupported in the absence of evidence of a contract "with the state."

The company's plea against impairment has not been confined to attempts to reduce rates. There are, for instance, a series of cases on the question whether, after having granted a franchise, the city itself may enter tho field with a municipal plant. In Walla Walla v. Walla Walla Water Co., 172 U. S. 1, 19 Sup. Ct. 77 (1898) the question was decided in favor of tho company. But an opposite result was reached in Hamilton Gas Light Co. v. Hamilton, 146 U. S. 258, 13 Sup. Ct. 90 (1892); Skaneateles Water Co. v. Skaneateles, 184 U. S. 354, 22 Sup. Ct. 400 (1902); Newburyport Wator Co. v. Newburyport, 193 U. S. 561, 24 Sup. Ct. 553 (1903); City. of Joplin v. Light Co., 191 U. S. 150, 24 Sup. Ct. 43 (1903); Helena Waterworks Co, v. Helena, 195 U. S. 383, 25 Sup. Ct. 40 (1904); Knoxville Water Co. v. Knoxville, 200 U. S. 22,26 Sup. Ct. 224 (1906). These cases, however, involve the entire policy of municipal trading and therefore are beyond the scope of the present discussion. 
years no longer provided a return equal to that accorded capital in other fields. Under such circumstances it was to be expected that the pre-existing contract would rapidly be stripped of its sanctity.

If, as in the case of valuations of the rate base, the change in price levels had simply changed the arguments of the state and the private operators, the issue might eventually have been settled on frank discussions of policy. But with the necessity for the shift there arose coincidentally the development of a strong centralized commission as opposed to the local authorities in the control of public utilities. The powers of regulation delegated to these state commissions were usually couched in terms so broad and comprehensive that the question soon arose as to what powers actually were retained by the local authorities. It was upon this question that the final stage of litigation over the public utility franchises rested.

The power of the state legislature itself to withdraw grants of authority from the local government had been recognized by the United States Supreme Court as early as 1850 in East Hartford v. Hartford Bridge Co. ${ }^{35}$ In that case the town, having in 1783 . been granted a franchise to operate a ferry across the Connecticut river, claimed that it had acquired contract rights that were impaired by an act of the legislature in 1818 which incorporated a bridge company and abolished the town ferry. The Court, however, held that no contract relation had been created between the legislature and the town. Again, in 1860, a New York court was asked to restrain the city of New York from leasing certain ferries to private companies, ${ }^{30}$ and, although denying the injunction on the ground that the correction of the abuse of a municipal function was a matter for legislative action, the court stated that the colonial charters from which the city derived its control of the ferries, were subject to control by the state legislature. ${ }^{37}$ Moreover, where the state legislature itself acts in favor of the company, the United States Supreme Court has decided that the city may not complain of impairment, since, even granting the existence of a contract, the state legislature supersedes the local council and may effect a change with the assent of the other party. ${ }^{38}$ But it is when the attempt is made to extend this rule to the acts of the state public service commission that the new problem arises.

${ }^{35} 10$ How. 511 (U. S. 1850). For a recent holding to the same effect compare City of Trenton v. New Jersey, 262 U. S. 182, 43 Sup. Ct. 534 (1923).

36 People v. Mrayor of New York, 32 Barb. 102 (N. Y. Sup. Ct. 1860).

${ }^{37} \mathrm{~A}$ comparatively recent instance of the same reasoning occurs in City of Pawhuska v. Pawhuska Oil Co., 250 U. S. 394, 39 Sup. Ct. 526 (1919).

${ }^{38}$ Worcester v. Worcester Consolidated Ry., 196 U. S. 539, 25 Sup. Ct. 327 (1905). 
Thus the litigation since the inflation of the prices during the World War has been largely concerned with the effect of an order of the state commission increasing rates upon the pre-existing provisions of the franchise granted by the city. Since the state commission seldom, if ever, has acted without a petition from the company, the situation, as has been pointed out, might be considered merely the reverse of that which gave rise to the Granger cases in the middle of the last century. ${ }^{39}$ But the important difference has been that the cases have usually been decided solely upon the question of the conflicting powers of the state commission and the city council. The usual result has been to sustain the ascendancy of the state commission. One method by which the courts have done this has been to take over the arguments used in the early cases to sustain the city's power to regulate. If the city had never in the beginning been authorized to make a contract it is obvious that a subsequent order of a state commission constitutes no impairment. This was the view of the United States Supreme Court in Englewood v. Denver \& South Platte Ry.,40 and it has been on similar grounds that many - of the state courts have upheld an increase granted by the state commission. ${ }^{42}$

39 It is interesting to note, however, that the question of determining the effect of the order of the state public service commission upon the provisions of a previously granted city franchise was presented to the United States Supreme Court in 1917 in a case where the company wes still complaining of impairment of the franchise. Puget Sound Traction, Light \& Powor Co. v. Reynolds, 244 U. S. 674, 37 Sup. Ct. 705 (1917). The caso concerned merely an order of the commission requiring the company to carry passengers beyond the limits set in the franchise. The Court sustained the order of the commission on the ground that the franchise itself provided that the company's rules were always to be in accordance with stato laws and the subsequent act creating the commission was reasonably within the purview of that condition. The Court also held that since at the timo the franchise was granted the state constitution provided that the legislature should have control over railway rates, it was beyond the power of the city to contract with the company. The case was distinguished from Detroit United Ry. v. Michigan, 242 U. S. 238, 37 Sup. Ct. 87 (1916) by the fact that in the latter case the state legislature had expressly granted the city the power to contract. The Court might have distinguished the case on firmer ground by the fact that in the Detroit case no order of the state commission was involved.

to 248 U. S. 294, 39 Sup. Ct. 100 (1919) ; cf. City of Paducah v. Paducah Ry., 261 U. S. 267, 43 Sup. Ct. 335 (1923).

11 Salt Lake City v. Utah Light \& Traction Co., 52 Utah 210, 173 Pac. 556 (1918); Sandpoint Water \& Light Co. v. City of Sandpoint, 31 Idaho 498, 173 Pac. 972 (1918) ; Traverse City v. Michigan Railway Commission, 202 Mich. 575, 168 N. W. 481 (1918); State ex rel. City of Billings v. Billings Gas Co., 55 Mont. 102, 173 Pac. 799 (1918); In re Searsport Water Co., 118 Me. 382, 108 Atl. 452 (1919); City of Sapulpa v. Oklahoma Natural Gas Co., 79 Okla. 196, 192 Pac. 224 (1920); City of Scranton v. Public Service Commission, $268 \mathrm{~Pa} .192,110$ Atl. 775 (1920); Washington 
It would seem, therefore, that if by language sufficiently clear and unmistakable the city had been given the power to make a contract, the franchise might be enforced in spite of a subsequent order by a state commission. But such is not the case. The courts, as well as ingenious counsel for the companies, were not content. The litigation of the past had produced such weighty cases in favor of enforcement of the contract as the Detroit case. ${ }^{2}$ Hence, there were many cases in which the contract itself had to be dissolved. It was not long before this was accomplished by means of more technical rules. The reasoning was as follows: (a) a contract exists; (b) but in making the contract the city acted only as "agent" for the state; (c) the state may at any time withdraw the agency from the city and repose it in a new body, the commission; (d) if the new agent agrees to an alteration of the contract, which is also acceptable to the company, both parties to the contract are satisfied and the city may not complain. ${ }^{\text {s }}$

But it is difficult to find among the cases of this kind a decision convincing even on purely technical grounds. For, where the city alleges impairment of its contract by another agency of the state the problem is not as easy as that in the early Hartford Bridge Co. case.s Here there really is some kind of agreement, not merely between the state and the city, but also between the city and the private company. On the other hand, the solution of the problem by means of technical rules of rescission or novation seems unsatisfactory because, after all, whatever be the theory of the relation of city and state, the parties to the agreement in any realistic sense are the company and the local interests. And it is further to be noted that none of the earlier cases in which the company was complaining against alleged impairment by the state and all its agencies can be applied. A few cases seem to have avoided these difficulties by overriding the franchise provisions on the simple ground that whatever be the relation between the city, as such, and the operating com-

v. Public Service Commission, 190 Ind. 105, 129 N. E. 401 (1921) ; Sambor v. Philadelphia Rapid Transit Co., 27 F. (2d) 406 (E. D. Pa. 1928).

Cf. also Black v. New Orleans Railway \& Light Co., 145 Lo. 180, 82 So. 81 (1919) and Lutes $\nabla$. Fayette Telephone Co., $155 \mathrm{Kg} .655,160$ S. W. 179 (1913), which hold that a citizen of the town cannot object to a modification agreed upon by the town and the company.

2 Supra note 33.

43 City of Portland $\nabla$. Public Service Commission, 89 Ore. 325, 173 Pac. 1178 (1918); City of Memphis v. Enloe, 141 Tenn. 618, 214 S. W. 71 (1919); City of Winfield v. Court of Industrial Relations, 111 Kan. 580, 207 Pac. 813 (1922), writ of error dismissed, 263 U. S. 680, 44 Sup. Ct. 133 (1923); Central Union Telephone Co. v. Indianapolis, 189 Ind. 210, 126 N. E. 628 (1920).

\footnotetext{
14 Supra note 35.
} 
pany, the superior police power to regulate is reserved by constitutional amendment.45 So direct is this method of dealing with the case that it would seem to justify a direct appeal to the court for revision of the rates set by the franchise. At least that view is implied in San Antonio v. San Antonio Public Service Co. ${ }^{40}$ where the Court says:

" ... if the contract right were conceded, there would, in view of the constitutional restriction, be such an inevitable conflict between the right and the dominant power to regulate as to render the contract right inoperative, and therefore to cause it to perish from the mere fact of admitting its conflict with the authority to regulate." 4

But even conceding this theory to be sound, the further question of the relation of the city's objection to the proper exercise of the police power is not settled, nor is the question of the extent to which the legitimate ends of the police power should be affected by an agreement between the city and the company. The problem is not merely to eliminate the agreement; rather it is to reconcile it with the wider policies of regulation.

Thus, where the courts are inclined to call the franchise " $a$ contract," rescission is possible only by recourse to the state commission. As was held in Columbus Railway, Power \& Light Co. v. Columbus, ss a franchise validly made is binding on the immediate parties and will not be set aside by direct proceedings for an injunction. This single rule of procedure adopted by the United States Supreme Court ${ }^{40}$ would seem to lend weight to the suggestion that a solution of the entire situation rests in determining the proper sphere for the franchise without either entirely eliminating it or endowing it with the rigidity of a technical contract. The rule has been stated as follows:

.. when the Water company applied to the Corporation Commission for an order increasing rates, it was bound by the

\footnotetext{
45 Western Oklahoma Gas \& Fuel Co. v. City of Duncan, 251 Pac. 37 (Okla. 1926) ; Mlinois Commerce Commission v. Township, 326 Ill. 65, 156 N. E. 766 (1927) ; Atlantic Coast Electric Ry. v. Board of Public Utility Commissioners, 92 N. J. L. 168, 104 Atl. 218 (1918), writ dismissed, 254 U. S. 660, 41 Sup. Ct. 10 (1920); Wilkinsburg v. Public Service Commigsion, $72 \mathrm{~Pa}$. Super. Ct. 423 (1919); State ex rel. City of Sedalia v. Public Service Commission, 275 Mo. 201, 204 S. W. 497 (1918), writ dismissed, 251 U. S. 547, 40 Sup. Ct. 342 (1918).

46255 U. S. 547, 41 Sup. Ct. 428 (1921) ; cf. Knoxville Gas Co. v. City of Knoxville, 261 Fed. 283 (C. C. A. 6th, 1919); City of Baton Rouge v. Baton Rouge Waterworks, 30. F. (2d) 895 (C. C. A. 5th, 1929).

47255 U. S. at 555, 41 Sup. Ct. at 431.

18249 U. S. 399, 39 Sup. Ct. 349 (1919).

19 St. Cloud Public Service Co. v. City of St. Cloud, 265 U. S. 352, 44 Sup. Ct. 492 (1924); Southern Utilities Co. v. City of Palataka, 268 U. S. 232, 45 Sup. Ct. 488 (1925).
} 
terms of the contract with the city contained in its franchise, to furnish water at a low schedule of rates fixed therein. It was not entitled to any judicial relief from this situation, however inadequate the rates.... Only by securing the waiver of the franchise rates by order of the Corporation Commission speaking for the state, did the water company have any standing to ask for a fixing of the rates in excess of the franchise rates."

The Supreme Court's decision in the Interborough Rapid Transit case ${ }^{51}$ would seem to imply a further restriction, since in that case it was held that even though the commission is known to be antagonistic toward the company, a federal court must not interfere before the state commission has acted. But, on the other side, the court in its recent Los Angeles case ${ }^{52}$ introduced new refinements on the question of what constitutes action by the state commission.

These rules of procedure do not eliminate the uncertainties and perplexities of the problem. The technical rules of contracts continue to give rise to anomolous decisions. Thus, it has been held that since a city has the authority to contract, the franchise must be construed in the light of any other contract and therefore any technical absence of "mutuality" will excuse the company from performance.5s Again, in Greensburg Water Co. $v$. Lewis, ${ }^{54}$ it was decided that where the company agreed to surrender its franchise in return for an indeterminate permit from the state legislature, the latter could not thereafter change the obligations said to rest in a new contract embodied in the indeterminate permit.

Difificulties are also to be found in the decisions of the same state. It has been held in Connecticut that cities have never had power to contract with public utilities for rates to the permanent exclusion of subsequent regulation by the state public service commission. ${ }^{55}$ Yet, in the same state, it has been de-

so Henderson Water Co. v. Corporation Commission, 269 U. S. 278, 281, 46 Sup. Ct. 112, 113 (1925). State courts apply a similar rule. Green v. San Antonio Water Supply Co., 193 S. W. 453 (Tex. Civ. App. 1917); Otsego v. Allegan County Gas Co., 203 Iuich. 283, 168 N. W. 968 (1918); City of Mobile v. Mobile Electric Co, 203 Ala. 574, 84 So. 816 (1919); City of University Place v. Lincoln Gas and Electric Co., 109 Neb. 370, 191 N. W. 432 (1922); Town of Pocahontas v. Central Light \& Power Co., 152 Ark. 276, 244 S. W. 712 (1922); Torn of Gallup v. Gallup Electric Light Co., 255 Pac. 724 (N. M. 1924).

51 Interborough Rapid Transit Co. v. Gilchrist, 279 U. S. 159, 49 Sup. Ct. 282 (1929).

s2 Supra note 1.

53 Nebraska Gas \& Electric Co, v. City of Stromsberg, 2 F. (2d) 518 (C. C. A. 8th, 1924); cf. Mr. Justice Brandeis' dissent in the Los Angeles case, supra note 1.

s4 189 Ind. 439,128 N. E. 103 (1920).

5s City of Ansonia v. Ansonia Water Co., 101 Conn. 151, 125 Atl. 474 
cided that an agreement made by a street railway to pay a municipality a certain per centum of its gross annual receipts as a condition for the use of the streets constitutes a contract which must be observed. ${ }^{56}$ So the situation in Connecticut as reflected by these recent cases seems to be that while a company cannot be bound to a limit of fare by contract with the city, as against the exercise of a "superior" police power, the same result may be reached by an agreement for a repayment of a per centum of fare receipts to the city. It would be interesting now to ascertain what consideration the Connecticut courts would give a contract for repayment of a per centum of receipts, in a case involving a determination of reasonable rates.

So also the Supreme Court of Virginia held in 1919 that since the state constitution and acts of the legislature expressly delegated authority to the cities to make franchise contracts with operating companies, the contract could be enforced against the companies even in the face of their plea of confiscation. The following year the court ratified an increase above a franchise maximum, which had been ordered by the state commission, on the ground that a contract was not set out.s8 Three years later the decision in the earlier case was expressly overruled. ${ }^{\circ 0}$ But, nevertheless, in 1925, it was held that the state commission was not empowered to dissolve a condition in a franchise that the company should pay the entire cost of paving between its rails..$^{60}$

But it is the record of cases decided by the courts in New York that defies analysis. When, in 1929, the United States Supreme Court issued an order for a rehearing in the Interborough Rapid Transit case, ${ }^{81}$ the country was startled by its condemnation of voluminous irrelevancies in counsel's original briefs. Criticism of that kind was a wholesome expression of discontent with the state of the law on the question. But counsel were perhaps merely the innocent victims not only of the tangle in the New York decisions but also of the Supreme Court's own terminological technique.

(1924); New Haven Water Co. v. City of New Haven, 106 Conn. 562, 139 Atl. 99 (1927).

${ }^{56}$ City of Hartford v. Connecticut Co., 107 Conn. 312, 140 Atl. 734 (1928).

${ }^{57}$ Virginia Western Power Co. v. Commonwealth, 125 Va. 469, 99 S. E. 723 (1919), certiorari denied, 251 U. S. 557, 40 Sup. Ct. 179 (1919).

58 City of Richmond v. Chesapeake \& Potomac Telephone Co., 127 Va. 512, 105 S. E. 127 . (1920).

59 Victoria v. Victoxia Ice, Light \& Power Co., 134 Va. 134, 114 S. E. 92 (1922); cf. Richmond v. Virginia Railway \& Power Co., 141 Va. 69, 126 S. E. 353 (1925).

6" City of Portsmouth v. Virginia Railway \& Power Co., 141 Va. 44, 126

S. E. 362 (1925).

62 Supra note 51. 
It would serve no good purpose to review the decisions in New York in detail. Attempts have been made to summarize the situation by citing the holding in People v. O'Brien ${ }^{\text {cs }}$ on the indefeasibility of franchise rights, and stating that the view of the New York courts is that the franchise contract is enforced between the parties but is subject to alteration by exercise of the state's superior police power, with the one exception that under constitutional amendments the city retains absolute control over the street railways. ${ }^{63}$ But that is merely a statement of generalities which might as appropriately be applied to the countrywide bulk of decisions on the subject; ${ }^{4}$ and neither in New York nor in the country at large has such an epitome of the situation been sufficiently accurate to check the flow of litigation. It is true that the New York court in Quinby v. Public Service Commis$\sin ^{65}$ seized upon a constitutional provision as evidence that the legislature had not intended that the authority of the state public service commission over the franchises of street railway companies should supersede that of the individual municipalities. But the underlying attitude seemed to be that the new statute ought not to be too liberally construed as divesting existing agencies of their control. When in the next year the court reached an opposite result where the franchise in question was that of a gas company, it became necessary to limit the scope of the decision in the Quinby case strictly to its facts. ${ }^{\circ 0}$ As might have been expected, the court was soon confronted with the problem of defining "a street railway," and in People ex rel. $N$. $Y$. W. \& B. Ry. v. Public Service Commission or it was held that the franchise of a line running out of New York City into the suburbs of Westchester county was not governed by the Quinby case. ${ }^{68}$

But the most striking example of the puzzle in New York was given in Interborough Rapid Transit Company v. Gilchrist." In that case a federal court of three judges granted an injunction restraining the state commission from enforcing the terms

6.2111 N. Y. 1 (1888).

63 Ransom, The Legislative Power, the Public Utility Rate and the Local Franchise (1919) 4 ConN. L. Q. 17.

6s Burdick, Regulating Franchise Rates (1920) 29 YALE L. J. 589. See also Note (1920) 9 A. L. R. 1165.

65 223 N. Y. 244, 119 N. E. 433 (1918).

c6 People ex rel. Village of South Glens Falls v. Public Service Commission, 225 N. Y. 216, 121 N. F. 777 (1919).

67 193 App. Div. 445, 183 N. Y. Supp. 473 (1st Dep't 1920), affd withont opinion, 230 N. -Y. 604, 130 N. E. 911 (1921).

es See also Mratter of United Traction Company y. Public Service Commission, 219 App. Div. 95, 219 N. Y. Supp. 421 (3d Dep't 1927).

6926 F. (2d) 912 (S. D. N. Y. 1928). For the grounds upon which the United States Supreme Court reversed this decision see supra note 51. 
of "contracts" between the operating company and the city of New York which stipulated that the fare to be charged on subways should be "the sum of five cents, but no more." To reach this conclusion it was necessary not only to reconcile numerous state laws from 1891 to 1913 in which the matter of rapid transit in New York City and the general question of statewide regulation of public utilities were alternately and successively treated, but also to weave into that pattern of legislation variations in the agreements between the city and the companies, and finally, to place the situation thus constructed under the federal cases.

But even this case does not touch all phases of the question in New York. Thus, in Public Service Commission v. Pavillion Natural Gas $\mathrm{Co}^{70}$ the court interpreted the provisions of the state laws to permit the company to increase rates on its own initiative, subject only to requirements of thirty days notice and the possibility of a subsequent hearing before the commission. It is true, of course, that these particular provisions do not apply to the regulation of rapid transit companies, but, nevertheless, on the general question as to how the rates of public utilities are to be controlled, they raise one more conflict in the chaos of New York legislation.

In striking juxtaposition with the doubts created by the Connecticut rulings, the contradictions in the Virginia cases, and the chaos in New York, are the decisions in the courts of Ohio. Even in the days when the public good seemed to demand the alterability of contracts and franchises, the Ohio courts stood out against the trend of opinion and insisted upon an observance of the terms of the railroad charters. ${ }^{12}$ And, subsequently, the United States Supreme Court held that the circumstances surrounding the franchise agreement between the city of Cleveland and the Cleveland City Railroxd bound the city to observe the terms of the agreement. ${ }^{22}$ So, too, in the following period of inflated prices when most courts and commissions have been favorably disposed towards the pleas for rates higher than those stipulated in their franchise agreements, the Ohio courts have consistently reversed attempts of the state commission in that state to alter contracts. ${ }^{73}$ The Ohio cases proceed merely upon the theory that municipalities have been given authority to enter binding agreements with the public utilities, and thus stand in direct opposition to the cases which maintain that the assump-

${ }^{70} 232$ N. Y. 146, 133 N. E. 427 (1921).

71 Iron Ry. v. Lawrence Furnace Co., supra note 12. But of. State v. Columbus Gaslight \& Coke Co., supra note 20.

72 Cleveland v. Cleveland City Ry., supra note 26; cf. Village of Wyoming v. Ohio Traction Co., 104 Ohio St. 325, 135 N. E. 675 (1922).

${ }^{73}$ Interurban Railway \& Terminal Co. v. Public Utility Commission, 98 Ohio St. 287, 120 N. E. 831 (1918) ; Cincinnati v. Public Utilities Commission, 98 Ohio St. 320, 121 N. E. 688 (1918); City of Lima v. Public 
tion of jurisdiction by the state commission is nothing more than a rescission by the two contracting parties, the state and the company. But, whatever may be the merits of the respective arguments, the fact remains that the state of the law in Ohio on this question is in a far more concise condition than elsewhere, and, it is to be supposed, the ends of regulation have been none the less achieved.

Such, then, is the far-flung result of those early cases which sought to circumvent the Dartmouth College decision. A doctrine of alterability, evolved to reduce rates to a conscionable level and curb the exorbitances attempted on the basis of the contracts, has become the tool of companies who no longer find profit in the role of Shylock. A century of technical refinements has produced a maze of uncertainties which serve but to obscure the major problem of regulation and raise false issues of rivalry between the local community and the state commissions. Just as the United States Supreme Court during the past term has been called upon to hark back over a bewildering past, so the future in all courts seems to hold out nothing but long and tedious litigation.

Yet there may be another escape. After all, the public utility problem is amenable to simple definition. It is nothing more than a question of measuring the terms upon which private agents are to be permitted to perform public functions. But where, in a particular case, the determination of such terms involves a previous agreement between the operators and the community to be served, it is misdirected reasoning to treat that agreement either as a technical contract or as the embodiment of metaphysical implications relating to the nature of political organisms. The public seeks good service at reasonable rates. It may further insist upon certain definite stipulations from the operators as to what will be considered reasonable. The franchise then becomes mere evidence from which to determine the scope of the operator's undertaking. But it is striking that in most of the cases the issue has been thought to lie between the contract rate and the reasonable rate as if the two were mutually exclusive and totally unrelated. The result has been that where alterability has been established the error in the contract rate, either as too high or as too low, has been assumed at the outset, or at most, hastily conceded as a kind of automatic minor premise. ${ }^{\text {T4 }}$ Or,

Utilities Commission, 100 Ohio St. 416, 126 N. E. 318 (1919); City of Columbus v. Public Utilities Commission, 103 Ohio St. 79, 133 N. E. 800 (1921); cf. Ohio Public Service Commission v. Fritz, 274 U. S. 12, 47 Sup. Ct. 480 (1927).

is See Judge Manton's opinion in the Gilchrist case, supra note 69. Another illustrative decision on this point is Cleveland Gaslight and Coke Co. v. City of Cleveland, 71 Fed. 610 (C. C. N. D. Ohio 1891). 
where the existence of the contract is admitted, the question of reasonableness is, as the United States Supreme Court has held, entirely irrelevant. ${ }^{\text {is }}$

Thus, in the recent case of Denny v. Pacific Telephone \& Telegraph $\mathrm{Co.}^{76}$ the oprrators applied to the state commission for an increase in rates above the franchise maximum. The commission found that the existing rates were reasonable, but on removal of the case to the federal courts, the question of confiscation was raised, and the district court granted relief. The state commission argued before the United States Supreme Court that under the Washington statute the commission alone was empowered to change a franchise rate and that a refusal to increase the rate was not confiscation. But the Court, in affirming the decision of the lower court, held that contention invalid. Not only is this decision, as the forerunner of the recent Los Angeles case, seemingly contrary to the Court's earlier ruling in the Columbus case ${ }^{77}$ and irreconcilable with the attitude, although perhaps not with the strict holding of the Court, in the subsequent Gilchrist case, ${ }^{78}$ but it also demonstrates an unfortunate absence of alertness to find a solution of the whole problem, and thus to accomplish the economy for which Mr. Justice Brandeis calls in his dissenting opinion in the Los Angeles case.

The question of reasonableness must always be decided at some point. But the importance of deciding it in relation to the franchise rate is that the franchise itself is necessarily involved in a determination of the measure of reasonableness. The United States Constitution has done much to clothe the reasonable rate with aspects of immutability, but reasonableness is still essentially a relative term. Even in the cases directly dealing with rate schedules where no franchise is involved the courts have been notoriously chary of establishing absolute standards. So then, it is possible to consider that where a company has accepted grants of power from a municipality in return for a presumably sincere agreement to observe a definite schedule of rates, the courts should demand something more than mere diminution of dividends as evidence of confiscation. Said the Court in the Columbus case:

"That there might be a rise in the cost of labor, and that the contract might at some part of the period covered become unprofitable by reason of strikes or the necessity for higher wages might reasonably have been within their contemplation when the contract was made, and provision made accordingly. ...

\footnotetext{
${ }^{75}$ Supra notes $48-50$; of. Georgia Railway \& Power Co. v. Town of Docatur, 262 U. S. 432,43 Sup. Ct. 613 (1923).

${ }^{78} 276$ U. S. 97, 48 Sup. Ct. 223 (1928).

${ }^{77}$ Columbus Railway, Power \& Light Co. v. Columbus, supra note 48.

${ }^{78}$ Interborough Rapid Transit Co. v. Gilchrist, supra note 51.
} 
Indeed, as we have said, there is no showing as in the nature of things there cannot be, that the performance of the contract, taking all the years together will prove unremunerative." to

In other words, where the court is compelled to find a binding contract, it will point to ameliorating circumstances on the question of confiscation, which, in the absence of the contract, would be determined on the narrow evidence of current figures. But there seems to be no reason for excluding the factual transactions between the company and the community as elements in the measure of reasonableness in all cases.

A variation of the rate might then proceed, as Judge Sanborn has suggested in one of his dissenting opinions, ${ }^{80}$ on the extent to which public interest demanded, rather than on a mere calculation of corporate profits and losses. Then, too, might centralized state commissions become the companions rather than the rivals of local communities in the solution of their public utility problems, as was soundly, though at the time futilely, suggested by the Virginia corporation commission in Commonzvealth ex rel. City of Clifton Forge v. Virginia Western Power Co.:

"It is proper to state that, while the Commission holds that it has no jurisdiction to hear and determine the matter as to whether the utility company is, in this case, entitled to an increase in its rates, the Commission stands ready to offer its services, in this and other cases where utility companies are seeking increases in rates beyond the maximum filed by ordinance contracts, to assist the local authorities in securing data necessary for a proper solution of the question." ${ }^{82}$

But the possibility of so direct and so satisfactory a cutting of the Gordian knot cannot perhaps be expected in the near future. The precedent of a century has become too firmly entrenched. Courts and counsel have tenacious memories, and, fortified by the cumulative growth of "due process of law," private capital in public utilities will not suffer.

79 249 U. S. at 414, 39 Sup. Ct. at 354; cf., State v. Home Telephone Co., 102 Wash. 196, 172 Pac. 899 (1918).

8o "Under the police power of the state and the statutes of Kansas the Commission has the jurisdiction and the authority to raise the rates for the service of public utility corporations prescribed by lawful contracts between it and others in cases where the agreed rates are confiscatory, unduly discriminatory and in cases where the good order, health, comfort and general welfare require such action; but in my opinion the jurisdiction of the Commission extends no further." Sanborn, Circuit J., dissenting, Public Utilities Commission of Kansas v. Wichita Railroad \& Light Co., 268 Fed. 37, 45 (C. C. A. 8th 1920).

81 P.U.R. 1918F 791, 809 (Va. St. Corp. Com. 1918). 